\section{Characterization of Hungarian touristical turnover 2006-2009 - focus on health tourism}

\author{
Katalin Kalmár \\ University of Debrecen Medical and Health Sciences Centre \\ Faculty of Health \\ HU-4400 Hungary, Nyíregyháza, Sóstói Str. 2-4. \\ Phone:42/404-411; email: kalmar.katalin@ foh.unideb.hu
}

\section{SUMMARY}

Tourism is one of the biggest and mostly increasing branch all over the world. Since it is getting more and more significant in Hungary as well in this article I analyze the turnover of Hungarian tourism on the basis of guest nights spent on commercial lodgings. I examine its changes in time and its territorial spreading. Finally I explore the health touristic volume, because it is one of the most important touristic product of Hungary and the North Plain Region and the infrastructure based upon preserves unique opportunities both for health and wellness tourism.

Key words: Hungary, touristic turnover, health tourism

\section{INTRODUCTION}

As a PhD Student of Debrecen I explore the marketing possibilities of the health tourism of our region. Recognizing the worldwide and national economic significance of tourism I considered to be important to examine the topic that is that of the tourism in Hungary and to compile the article.

\section{METHOD}

While compiling the study I applied a secondary exploration. The basis of present analysis are detailed tables of guest nights numbers spent at commercial lodgings published on a yearly basis at the data basis of Hungarian Central Statistical Office and a further basis are information and data to be found at web page of Hungarian Tourism Ltd.

I applied methods of basic statistics during my analysis: by means of distributional correlations I made diagrams examining spatial and timely change of data.

\section{RESULTS}

Tourism is one of the biggest and quickest developing branch all over the world.

The GDP of our country is 129017 million dollars out of which 1657 million dollars come from tourism (Source: HT Ltd., 2010). Tourism plays an outstanding role in improving the foreign trade balance and it builds a more and more significant segment in employment (more than 300 thousand people ) it has got a positive effect also on quality of life by its multiplications. After having recognized the significance of the branch and the further opportunities of improving the tourism it deserves more and more attention in domestic politics of development that is why I considered it to be important to analyze the turnover realized in our country.

\section{Analysis of the touristic turnover of Hungary}

In Hungary foreign and domestic tourists spent 18.28 million guest nights at commercial accommodations in 2009. The falling back is the effect of crisis. Based on the data of the first six months of 2010 one can say obviously that there is an improvement both in the number of guests and the spent guest nights nevertheless this does not raise the turnover on the level of 2008. Related to the summarized data of domestic and foreign guests it can be experienced that the guest nights spent are distributed into an almost 50-50 per cent. While until 2008 the balance was in favorite of foreign guests the year of 2009 has nevertheless been featured by a bigger proportion of inland tourists though these differences are so to say insignificant. Furthermore it can be stated that the number of foreign guest nights decreased by about 1 million in the four years explored however the number of domestic guest nights is less in a much more modest extent.

Going on with the exploration of turnover of commercial lodgings it is worth emphasizing the attractive force of regions.

Among the regions Budapest-Middle Danube Country stands at first place both in relation to guest numbers and to guest nights spent. The greatest attraction of this region is Budapest without any doubt. Henceforth the biggest lake of Hungary, Balaton respectfully the Balaton region are also popular destinations. North Plain Region is considering number of guests at 5th place and considering guest nights it has the 4th place.

Compared to data of previous year every region shows a decreasing tendency though Middle Western Hungary is remarkable from this point of view where the number of guests and guest nights decrease by half respectfully one and a half per cent whereas in the other regions there are experienced much bigger differences reaching 5.7 even sometime 10 to 12 per cent.

Testing distribution of home and foreign guests once again Budapest-Middle Danube Country region must obviously be emphasized that is not only an unambiguous winner of a ,contest" among the regions, but it also differs from the average insofar the proportion of foreign guests is extraordinarily high. Here 80 per cent of guest nights come from foreign guests that is an enormously important factor 
also in relation to the currency spent. In the other regions proportion of home guests is about 60 to 70 per cent. Foreigners' preference is least to NorthernHungarian region, here they have a proportion of under 20 per cent.

Following a description of touristic regions I explore a distribution of turnover among the types of commercial accommodations:

In 2009 there were 18.28 million guest nights spent at commercial accommodations and more than 70 per cent of them at hotels which means almost 13 million guest nights. It is remarkable that almost 56 per cent of the guest nights derive from foreigners. The remaining 30 per cent covers 5.3 million of guest nights. These have the order of pensions, touristic accommodations, youth hostels, apartments and campings. The proportion of these accommodation types is under 10 per cent each. The highest one of these is the proportion of pensions (9.86 per cent) with 1,8 million of guest nights. Least added up guest nights have been spent at tourist accommodations or youth hostels (3 per cent each).

Distribution of home and foreign guests campings and hotels must be emphasized especially where guest nights spent by foreigners dispose of an exceedingly high proportion (65. 68 per cent). In case of the other accommodations a predominant proportion of home guests is characteristic. Above figures are displayed by me on diagram 1 .

Diagram 1: Distribution of guest nights among the commercial accommodations in 2009

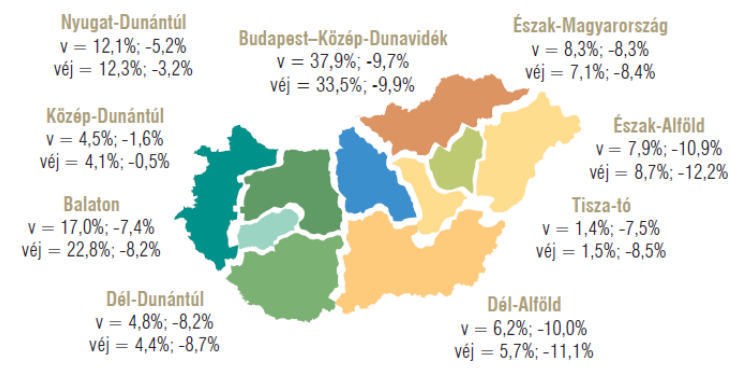

( v= guests; Véj=guest nights; Budapest-Közép-

Dunavidék=Central Hungary, Budapest and its surroundings; Észak-Magyarország=Northern Hungary; Észak-Alföld=Northern Great Plain; Tisza-tó=Lake Tisza; Dél-Alföld=Southern Great Plain; Dél-Dunántúl=Southern Transdanubia; Balaton= Lake Balaton; Közép-Dunántúl=Central Transdanubia; NyugatDunántúl=Western Transdanubia; )

Source: HT Ltd.

It can be seen on the diagram 1 that the biggest proportion is represented by hotels. As there are almost 13 millions of guest nights spent at hotels, in the followings I explore the division of number of nights among hotels of various quality is 42 per cent of 13 millions of guest nights at hotels altogether 5.5 millions of nights have been spent at 4- star hotels, 5.15 millions of nights ( 40 per cent) have been spent at 3-star hotels, so these two categories are most preferred. 5-star hotels share 11 per cent in guest nights whereas 2-star hotels own 6 per cent with 732 thousand guest nights.

Diagram 2: The distribution of overnight stays in commercial accommodation in 2009

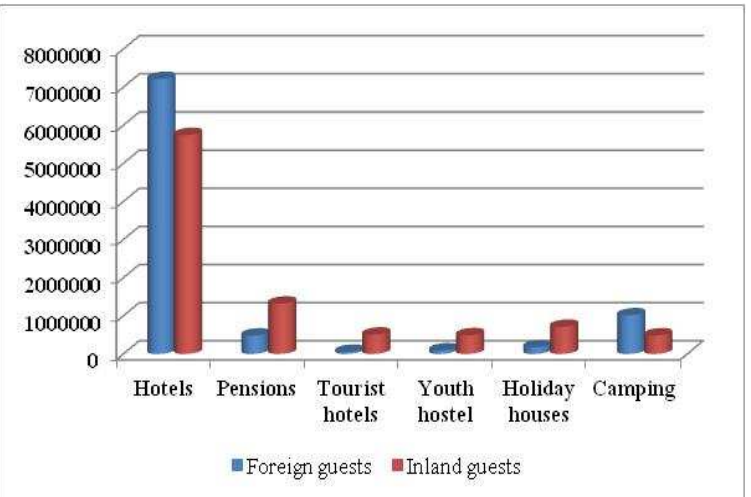

Source: KSH., own editing

At 5-star hotels proportion of guest nights spent by foreigners is 85 per cent. Similarly the proportion of foreigners is higher at 4-star hotels (58 per cent), while in the other hotels of lower category the proportion of inlanders is determinant. As for the figures (Diagram 2) it can be said that the number of nights spent by inlanders is directly proportional to decrease of star numbers. Furthermore I would like to explore the role of guest nights having spent with a health touristic purpose. Two major pillars of health tourism are medicinal and wellness tourism. Data of hotels specialized for prevention and cure or rehabilitation or the basis of examination I took from the statistical data to be found on the web page of Hungarian Tourism Ltd.

\section{Significance of health tourism in Hungary}

„Hungary is a thermal water great power”-as Iván Róna the former general director of Hungarian Tourism Joint-stock company emphasized in his presentation at the IInd Thermal and Wellness Health Touristic Exhibition in 2009. Lajos Fazekas, the president of the Thermal-Health Care Claster ranked Hungary at the same time with the ,health touristic great powers" of Europe as a result of the developments based on the hidrogeological conditions. (Source: North Plain Thermal Claster Society, 2009.)

The facts are unambiguous:

- In an international correlation our country belongs to the first five countries rich in thermal water. There is thermal water under 80 per cent of our country's territory, a great part of which is due to oil boring experiments of the 50-ies. Owing to improvements in many waves ever since health tourism became the most dynamic and determining element of Hungarian touristic supply. (Source: National Health Touristic Development Strategy, 2007) 
- Beyond the increase of the number of baths a complex improvement of attending infrastructure is to be stressed as well as the forming of organs of controlling and

- representation of interests the preparation of a marketing conception and a national development strategy.

- Health tourism has been backed by the government also between the Regional Operative Programs of 2007-2009 by developing baths and connecting accommodations.

- In the system of themes of Hungarian Tourism Ltd 2008 was the ,Year of Waters" and 2011 was stressed the Year of Health Tourism. (Source: MT Ltd., 2011)

Also many home touristic bath explorations verified that bath attenders take advantage not only of medical services, but claim also the habitual spare time, sport and wellness services. Bath visits have thus become part of everyday programs since by extension of their supply they provide good opportunities for a regular physical training, for connecting the body care, relaxation and rest and for the preservation of health. (Könyves et al., 2005.; Müller-Könyves, 2006; Könyves-Müller, 2007; Müller-Kórik, 2009; Müller et a.l, 2009; Kerényi et a.l, Mosonyi et a.l, 2010).

In the following I would like to inquire into the role of guest nights spent with a health touristic purpose. The two main pillars of health tourism are cure and wellness tourism. The data of hotels specialized on prevention and cure or rehabilitation or the basis of the inquire I took from the statistical figures at the web page of Hungarian Tourism Ltd.

16.5 per cent of commercial accommodation are to be found at cure and wellness hotels. 19.9 per cent of guests take advantage of health touristic services that makes 22.5 per cent of guest nights. Cure and wellness hotels call 24.9 per cent of inland guests and 26.1 per cent of inland guest nights their own. 13.8 per cent of foreign guests choose these accommodations resulting in 18.8 per cent of foreign nights. The average time of stay is more than the commercial average. Since at cure hotels the proportion of inland and foreign turnover is about the same whereas it is 74.6 per cent in case of home guests at wellness hotels. I illustrate the turnover of cure and wellness hotels in diagram 3.
Diagram 3: Turnover of cure and wellness hotels 2006-2009. (number of guest nights)

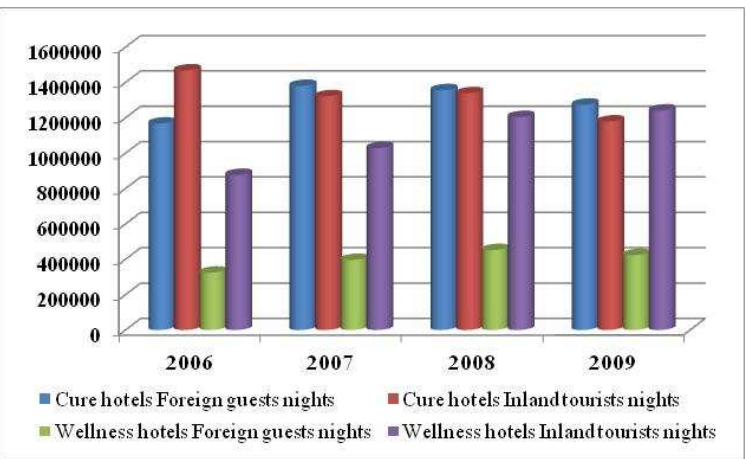

Source: HT Ltd. and KSH., own editing

The number of guest nights as well as the number of guest nights spent at cure hotels decreased by 8 per cent in the inquired 4 years. Reflecting this fact one has to point it out that in this critical period number of guest nights spent in wellness hotels increased. From 2006 to 2009 the turnover of wellness hotels increased by 30 per cent. Though the number of nights spent at cure hotels exceeds the relevant figures of wellness hotels this outstanding result and the dynamism of increase is remarkable.

\section{CONCLUSIONS}

In Hungary there have been spent 18.28 millions of guest nights at commercial accommodations by foreign and inland guests altogether. More than 70 per cent has been spent at hotels that covers almost 13 million of guest nights. It is remarkable that almost 56 per cent of hotel guest nights come from foreign guests. From among the regions BudapestMiddle-Danube Country stands at the first place considering both the guest numbers and the guest nights spent. Besides Balaton, the biggest lake of Hungary and the Balaton region are popular destinations. North Plain Region stands at 5th place in respect of guest numbers and at 4th place in respect of guest nights spent. 16.5 per cent of commercial accommodations in Hungary can be found at cure and wellness hotels.

On the basis of the significance of health tourism and of the analysis of turnover data it can be said that while the most dynamically developing branch of tourism is health tourism, it is wellness tourism inside of health tourism that has to be paid attention to.

\section{LITERATURE}

Anetta Müller-Valéria Kórik (2009): Role of Northern Plain baths in tourism and recreation. In. Economica Nr. 2009/2.Attila Mosonyi - Erika Könyves - Erika Kerényi - Anetta Müller (2010): Health Tourism of Miskolctapolca reflected by an examination. International Conference of Tourism, Recreation and Sports Management. 27-28th May 2010.vol. of publ. (CD) p.8.
Aquaprofit (2007): National Health Tourism Development Strategy, Budapest. p. 28-31.

http://www.bm.gov.hu/web/portal.nsf/dokumentumtar/B8B54 510996E5A51C125757E00349EDD/\$file/Egeszsegturizmusst rategia.pdf?OpenElement

Erika Kerény-Anetta Müller-Róbert Szabó-Attila Mosonyi (2009): Analysis of Agárd, Komárom and Pápa's Thermal and Experiences Bath, according to guest's satisfaction. 
Publication of Conference of Health Care Marketing and Telecommunication (CD)ISBN-978-963-06-8473-6., p 11.

Erika Könyves-Anetta Müller (2007): Awarding the quality prize in the marketing communication device system of health touristic suppliers. In: Acta Academiae Pedagogicae Agriensis. New Series XXXIVth Vol. Inquiries int he field of sports science and health tourism. Eger 2007. 57-71 p.

Erika Könyves-Anetta Müller-Ferenc Szalay-Róbert Szabó (2005): A comparative analysis of health tourism of Cserkeszőlő and Karcag. The Day of the Hungarian and World Science. Szolnok. 10. Nov. 2005. In: Szolnoker Scientific Notices IX. (Ed. Szabolcsi R-Kádár Z.-Pelikán L.) ISSN: 1419-256-X.

Erika Könyves-Anetta Müller.:(2006) Possibilities of health tourism in the Northern Plain Region. In: Acta Academiae Pedagogicae Agriensis- Scientific Publications of Eszterházi Károly College. XXXIIIth Volume. Eger. p 132-144.
Erika Kerényi-Anetta Müller-Róbert Szabó-Attila Mosonyi (2009): Bath exploration in the Middle Western Region. In: Acta Academiae Pedagogicae Agriensis. XXXVI. Sectio Sport. Sports, way of life, health. Scientifi publications of Eszterházy Károly College. (Ed.: Honfi László) p. 65-77.

Web page of Hungarian Tourism Ltd., http://itthon.hu/szakmaioldalak/statisztikai-adatok/statisztikai-adatok\#_2009;

Webpage of KSH,

http://statinfo.ksh.hu/Statinfo/themeSelector.jsp?page=2\&szst $=\mathrm{OGA}$

Web page of North Plain Thermal Claster: http://www.thermalklaszter.hu/hun/main.php?f=kiir\&oid=97 $\&$ mid= $1 \&$ kid $=173$;

http://www.thermalklaszter.hu/hun/data/fazekaslajos_termalegeszsegipariklaszterbemutatasa_20100310-102113.pdf; 